Tabularasa: Jurnal Ilmiah Magister Psikologi, 1(2) 2019: 105-115,
D0I: $\begin{gathered}\text { Tabularasa: Jurnal IImiah Magister Psikologi } \\
\text { Available online http://jurnalmahasiswa.uma.ac.id/index.php/tabularasa } \\
\text { Diterima: 11 Januari 2020; Disetujui: 11 Februari 2020; Dipublish: 11 Maret } 2020\end{gathered}$

\title{
Hubungan Pola Asuh Demokratis dan Interaksi Teman Sebaya dengan Kecerdasan Emosional Siswa Kelas V Madrasah Ibtidaiyah Negeri 1 Bebesen
}

\section{The Relationship Between Democratic Parenting and Peer Interaction with Emotional Intelligence in Fifth Grade Students of Madrasah Ibtidaiyah 1 Bebesen}

\author{
Atika Sabaria*, Abdul Munir \& Cut Metia \\ Program Studi Magister Psikologi, Program Pascasarjana,Universitas Medan Area
}

\begin{abstract}
Abstrak
Penelitian ini bertujuan untuk mengetahui hubungan pola asuh demokratis dan interaksi teman sebaya dengan kecerdasan emosional. Hipotesis yang di ajukan adalah ada hubungan positif antara pola asuh demokratis dan interaksi teman sebaya dengan kecerdasan emosional yaitu semakin tinggi pola asuh demokratis dan interaksi teman sebaya maka semakin tinggi kecerdasan emosional. Populasi dalam penelitian ini berjumlah 113 orang dan sampel dalam penelitian ini berjulah 85 orang. Metode yang digunakan dalam penelitian ini adalah metode kuantitatif dengan teknik pengambilan sampel menggunakan teknik total sampling. Bentuk skala dalam penelitian ini menggunakan skala Guttman dengan koefisien reliabilitas pada pola asuh demokratis sebesar 0,903 pada interaksi teman sebaya sebesar 0,764 dan pada kecerdasan emosional sebesar 0,888 . Analisis data menggunakan analisis regresi berganda dan korelasi parsial. Berdasarkan hasil penelitian disimpulkan bahwa terdapat hubungan yang signifikan antara pola asuh demokratis dan interaksi teman sebaya dengan kecerdasan emosional, yang ditunjukkan oleh koefisien $r=0.518$; dengan $p=0.00$ berarti $(p<0,01)$ artinya semakin tinggi pola asuh demokratis dan interaksi teman sebaya maka semakin tinggi kecerdasan emosional. Berdasarkan mean empirik dan mean hipotetik variabel pola asuh demokratis dalam penelitian ini adalah $(70.106>57.00)$, variabel Interaksi teman sebaya $(44.047>36.00)$, dan variabel kecerdasan emosi adalah $(64.176>52.500)$ diketahui bahwa subjek penelitian memiliki pola asuh demokratis, interaksi teman sebaya dan kecerdasan emosional yang tinggi. Kata Kunci: Pola asuh demokratis, interaksi teman sebaya, kecerdasan emosional
\end{abstract}

\begin{abstract}
This research aims to determine the relationship between democratic parenting and peer interaction with emotional intelligence. The hypothesis proposed, there is a positive relationship between democratic parenting and peer interaction with emotional intelligence, the higher democratic parenting pattern and peer interaction, so the emotional intelligence will be the higher also. The population in this research amounted to 113 people and the sample in this research amounted to 85 people. The method that researchers use is quantitative and for take a sampling technique researchers using total sampling technique. Scale form in the researchers using Guttman scale with the coefficient of reliability in democratic parenting of 0.903 on peer interaction of 0.764 and on emotional intelligence of 0.888. Data analysis that researchers used is multiple regression analysis and partial correlation. Based on the result, researchers concluded that there is a significant relationship between democratic parenting and peer interaction with emotional intelligence, as shown by coefficient $r=0.518$; with $p=0.00$ means $(p<0.01)$ it's means that the higher the democratic parenting pattern and peer interaction so the emotional intelligence will be the higher also. Based on the empirical mean and hypothetical variables mean of democratic parenting in this research is (70.106> 57.00), Interaction variables of peers (44.047> 36.00), and emotional intelligence variables $(64.176>52.500)$ known that the subject of research has a democratic parenting, interaction peers and high emotional intelligence.
\end{abstract}

Keywords: Democratic parenting, peer interaction, emotional intelligence

How to Cite: Sabaria, A., Abdul, M., Cut, M. (2019). Hubungan Pola Asuh Demokratis dan Interaksi Teman Sebaya dengan Kecerdasan Emosional Siswa Kelas V Madrasah Ibtidaiyah Negeri 1 Bebesen. Tabularasa: Jurnal Ilmiah Magister Psikologi, 1(2) 2019: 105-115,

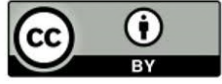


Atika Sabaria, Abdul Munir, Cut Metia, Hubungan Pola Asuh Demokratis dan Interaksi Teman

\section{PENDAHULUAN}

Kecerdasan emosional terlibat dalam kapasitas untuk merasakan emosi, mengasimilasi perasaan yang berhubungan dengan emosi, memahami informasi dari emosi, dan mengelolanya. Pelajaran-pelajaran emosi yang diperoleh semasa kanak-kanak, dirumah dan disekolah akan membentuk sirkuit-sirkuit emosi, membuat anak cakap atau tidak cakap dalam dasar-dasar kecerdasan emosional. Hal ini berarti masa anak-anak merupakan peluang terbuka yang penting untuk mengarahkan kebiasaan-kebiasaan emosional yang esensial yang akan menentukan kehidupannya (Goleman 2016).

Kecerdasan emosional sangat dipengaruhi oleh faktor lingkungan keluarga (pola asuh orang tua), lingkungan luar keluarga (sekolah dan interaksi teman sebaya), tidak bersifat menetap dan dapat berubah-ubah setiap saat. Untuk itu peranan lingkungan terutama orang tua dan lingkungan luar keluarga sangat mempengaruhi dalam pembentukan emosional khususnya pada masa anak-anak.Mubayidh (2007)

Salah satu pola asuh yang dapat mengembangkan kecerdasan emosional anak adalah pola asuh demokratis. Pola asuh orang tua memiliki peran yang sangat penting terhadap perkembangan kecerdasan emosional pada anak. Kegagalan pola asuh orang tua sering kali menjadi faktor penyebab terjadinya gangguan pada perkembangan kecerdasan emosional anak. Ketetapan orang tua dalam menerapkan pola asuh memberikan pengaruh yang sangat besar terhadap emosional anak.

Berbagai penelitian membuktikan adanya kaitan erat antara emosional dengan pola asuh orang tua. Peran dan keterlibatan orang tua dalam pelaksanaan pola asuh sangat diperlukan untuk mengembangkan kecerdasan emosional anak.

Pola asuh yang dilihat dari sikap dan perilaku orang tua terhadap anak bervariasi. Kebervariasian pola asuh membawa pengaruh yang berbeda-beda pula pada anak. Pola asuh yang diterapkan orang tua mempengaruhi perkembangan kepribadian anak sebagai salah satu aspek perkembangan yang sifatnya dinamis (Pandia, et al., 2015; Hartaty \& Azis, 2014; Novita, 2012; Hasmayani, 2012; Salamiah et al., 2011; Fadilah, 2020). Sikap positif orang tua yang terbaca oleh anak, akan menumbuhkan pandangan yang positif serta sikap menghargai diri sendiri. Salah satu pola asuh yang dapat mengembangkan kecerdasan emosional anak adalah pola asuh demokratis. Soeloeman (dalam Wulansari 2014) mengungkapkan bahwa di dalam keluarga yang menerapkan pola asuh demokratis, seorang anak akan memperoleh latihan-latihan dasar dalam mengembangkan sikap sosialnya yang baik dan kebiasaan berperilaku. Sikap sosial dan kebiasaan berperilaku merupakan kecerdasan emosional. Anak yang memiliki kecerdasan emosional yang baik akan lebih mudah menyesuaikan diri dengan lingkungan, terutama dengan teman sebayanya dan dapat berlaku ramah dengan orang lain (Hamdani, et al., 2015; Zuraida, et al., 2015; Harahap, et al., 2014; Syarifah \& Darmayanti, 2010).

Interaksi dengan teman sebaya akan memberikan pengalaman yang berbeda dari keluarga. Perbedaan pengalaman dalam keluarga dan di luar keluarga membuat anak beradaptasi dengan bantuan teman sebaya. Bagi anak usia sekolah, teman sebaya (peer) mempunyai fungsi yang hampir sama dengan orangtua. Hal ini bisa disebabkan karena teman sebaya dapat memberikan pengaruh lebih kepada perilaku anak, baik perilaku positif maupun perilaku negatif. Hartub (dalam Desmita, 2007).

Ammar (2014) pada penelitiannya menyimpulkan kaitan erat antara interaksi teman sebaya dengan kecerdasan emosional, dalam berinteraksi, kemampuan mengenali emosi orang lain dan membina hubungan semakin terasah. Interaksi yang tinggi dan bersifat positif mampu mengembangkan kemampuan-kemampuan kecerdasan emosional. Pada 
masa kanak-kanak akhir kelompok sebaya berdasarkan gender mulai terbentuk. Terkadang terjadi saling maki antar kelompok sebaya tersebut. Jika ada salah satu siswa dalam kelompok berani menentang orang yang lebih tua maka siswa lain dalam kelompok akan melakukannya juga.

Berdasarkan hasil wawancara dengan guru kelas dan pengamatan peneliti didapat data bahwa tingkat partisipasi orang tua dalam memantau perkembangan anak rendah. Komunikasi antara guru dan orang tua masih kurang. Guru lebih aktif memberikan informasi kepada orang tua jika anaknya bermasalah di sekolah. Tetapi orang tua kadangkadang menolak pengakuan guru yang mengatakan anaknya bermasalah karena merasa anaknya di rumah baik-baik saja, tidak nakal. Hanya sebagian orangtua yang memantau perkembangan anaknya secara rutin. Sebagian hanya menanyakan keadaaan anaknya di sekolah pada saat penerimaan raport. Guru kelas menyampaikan bahwa beberapa anak sering mengalami masalah di sekolah, yaitu masih ada anak yang berperilaku mencerminkan ketidakstabilan emosi. Berdasarkan hasil observasi yang dilakukan ditemukan beberapa fakta permasalahan di sekolah.

Berdasarkan hasil observasi yang dilakukan ditemukan beberapa fakta permasalahan di sekolah. Anak-anak sering berkata kasar terhadap teman sehingga menimbulkan perkelahian anak yang mendapat makian dari temannya akan membalas memaki-maki temannya dengan kata-kata kasar. Beberapa anak sering mengganggu temannya yang sedang diam sehingga anak yang di ganggu menjadi marah, bahkan ada anak yang mengungkapkan rasa marahnya dengan serangan fisik seperti memukul, menendang. Masih ada beberapa dari siswa disekolah tersebut yang keluar pada saat jam sekolah masih berlangsung, ditemukan juga perilaku anak yang mudah cemas ataupun mudah marah, sombong serta angkuh membuat keributan di lingkungan sekolah ketika jam istirahat, rendahnya empati, cuek, dan suka berkelahi cenderung egois dan tidak peduli terhadap lingkungan sosialnya serta cenderung mengharapkan balasan ketika menolong orang lain.

\section{METODE PENELITIAN}

Metode yang digunakan dalam penelitian ini adalah metode kuantitatif. Yang bertujuan untuk mengetahui hubungan pola asuh demokratis dan interaksi teman sebaya dengan kecerdasan emosional.

Populasi dalam penelitian ini adalah siswa-siswi kelas V yang ada di MIN 1 Bebesen Takengon Kabupaten Aceh Tengah berjumlah 113 orang yaitu 54 orang laki-laki dan 59 orang perempuan. Berdasarkan hasil screening dari 113 orang hanya 85 orang yang mencorakan pola asuh demokratis.Teknik pengambilan sampel dalam penelitian ini menggunakan teknik total sampling. Hasil sampel dalam penelitian ini sama dengan populasi, adapun sampel yang di ambil dalam penelitian ini berjumlah 85 orang.

Penelitian dilaksananan di Madrasah Ibtidaiyah Negeri 1 Bebesen Takengon Kabupaten Aceh Tengah, penelitian ini dilakukan pada tanggal 15 s/d 17 November 2016.

Defenisi operasional dalam penelitian ini yaitu variabel pertama: pola asuh demokratis merupakan pola asuh yang memprioritaskan kepentingan anak, akan tetapi tidak ragu-ragu mengendalikan mereka, dimana orang tua menentukan peraturanperaturan tetapi dengan memperhatikan keadaan dan kebutuhan anak, melakukan apa yang diinginkannya dengan tidak melewati batas-batas atau aturan-aturan yang telah ditetapkan orang tua. Pola asuh demokratis diukur dengan menggunakan skala pola asuh demokratis yang disusun berdasarkan enam aspek pola asuh demokratis yang dikemukakan oleh Munandar (dalam Wulansari 2014) yaitu adanya musyawarah dalam keluarga, adanya kebebasan yang terkendali, adanya pengarahan dari orang tua, adanya 
bimbingan dan perhatian, adanya saling menghormati antar anggota keluarga dan adanya komunikasi dua arah. Variabel kedua Interaksi teman sebaya adalah suatu hubungan sosial antar individu yang mempunyai tingkatan usia yang hampir sama, serta di dalamnya terdapat keterbukaan, tujuan yang sama, kerjasama serta frekuensi hubungan dan individu yang bersangkutan akan saling mempengaruhi satu sama lainnya. Interaksi teman sebaya diukur dengan menggunakan skala interaksi teman sebaya yang disusun berdasarkan tiga aspek interaksi teman sebaya yang dikemukakan oleh Partowisastro (dalam Ahmad, 2009) yaitu: keterbukaan individu, kerjasama individu dalam kelompok, frekuensi hubungan individu dalam kelompok. Variabel ketiga Kecerdasan emosional adalah kemampuan emosi dalam berinteraksi dengan teman sebaya dan lingkungan keluarga yang mencakup, pengendalian diri, mampu memantau perasaan diri sendiri dan orang lain, memiliki daya tahan ketika menghadapi suatu masalah, memotivasi diri, mampu mengatur suasana hati, kemampuan berempati dan membina hubungan dengan orang lain. Kecerdasan emosional diukur dengan menggunakan skala kecerdasan emosional yang disusun lima aspek kecerdasan emosional yang di kemukakan oleh Goleman (2016) yaitu mengenali emosi diri, mengelola emosi, memotivasi diri sendiri, mengenali emosi orang lain, membina hubungan.

Metode pengumpulan data dalam penelitian ini menggunakan metode skala. Penelitian ini menggunakan tiga skala yang disusun sendiri oleh peneliti. Pertama skala yang dimaksudkan adalah skala untuk mengumpulkan data tentang pola asuh demokratis, interaksi teman sebaya dan kecerdasan emosional siswa.

Skala yang digunakan dalam penelitian ini adalah skala guttman dengan dua pilihan jawaban. Variabel yang akan di ukur dijabarkan menjadi indikator yang dijadikan pedoman penyusunan skala dengan dua pilihan jawaban. Responden memberikan jawaban. Respon jawaban diberikan dengan menggunakan tanda $(\sqrt{ })$ pada skala yang disediakan. Penilaian yang diberikan kepada masing-masing jawaban subyek pada setiap pertanyaan favourable adalah (Ya) mendapat nilai 1 dan (Tidak) mendapat nilai 0 , sedangkan untuk pertanyaan yang unfavourable penilaian yang diberikan adalah (Ya) mendapat nilai 0 dan (Tidak) mendapat nilai 1.

Penyusunan skala diawali dengan penyusunan blue print. Penyusunan blue print ini bertujuan agar skala yang dibuat mampu memberikan informasi sesuai kebutuhan dan tujuan penelitian.

Setelah ketiga skala diujicobakan, data yang diperoleh tersebut diolah untuk menentukan item-item mana saja yang valid dan dapat dijadikan sebagai item dalam penelitian. Validitas alat ukur ditentukan dengan menggunakan teknik product moment dari Karl Pearson dan reliabilitas alat ukur ditentukan melalui teknik koefisien alpha dari Cronbach.

Untuk menguji hipotesis pada penelitian ini menggunakan teknik analisis regresi berganda untuk mengetahui hubungan antara pola asuh dan interaksi teman sebaya dengan kecerdasan emosional. Dan uji Korelasi parsial digunakan untuk mengetahui pengaruh antara variabel independen dan dependen dimana salah satu variabel independennya dibuat tetap/dikendalikan. Korelasi parsial merupakan angka yang menunjukkan arah kuatnya hubungan antara dua variabel setelah variabel yang diduga dapat mempengaruhi dikendalikan.

\section{HASIL DAN PEMBAHASAN}

Analisis data yang dilakukan dalam penelitian ini terlebih dahulu uji asumsi yaitu uji normalitas dan uji linieritas.Uji normalitas digunakan untuk mengetahui apakah skor tiap-tiap variabel berdistribusi normal atau tidak (Hadi, 2004). Uji normalitas ini dihitung 
dengan menggunakan rumus Kolmogorov-Smirnov. Sebagai kriterianya apabila $p>0,050$ dinyatakan normal. (Nisfiannoor, 2009). Tabel 4.7 berikut ini merupakan rangkuman hasil perhitungan uji normalitas sebaran.

Tabel 4.7.

Rangkuman Hasil Perhitungan Uji Normalitas Sebaran

\begin{tabular}{cccccc}
\hline Variabel & RERATA & SD & K_S & $\mathrm{p}$ & Ket \\
\hline $\begin{array}{c}\text { Pola Asuh } \\
\text { Demokratis }\end{array}$ & 70.106 & 3.512 & 1.374 & 0.057 & $\mathrm{~N}$ \\
\hline $\begin{array}{c}\text { Interaksi } \\
\text { Teman } \\
\text { Sebaya }\end{array}$ & 44.047 & 2.444 & 1.129 & 0.156 & $\mathrm{~N}$ \\
\hline $\begin{array}{c}\text { Kecerdasan } \\
\text { Emosional }\end{array}$ & 64.176 & 4.403 & 1.285 & 0.074 & $\mathrm{~N}$ \\
\hline
\end{tabular}

Hasil uji asumsi normalitas sebaran terhadap variabel pola asuh demokratis menghasilkan nilai $\mathrm{Z}=1.374$. dan $\mathrm{p}=0.057$ ( $\mathrm{p}>0.05)$; untuk variabel interaksi teman sebaya menghasilkan nilai $Z=1.129$, dan $p=0,156(p>0,05)$; dan untuk variabel kecerdasan emosional menghasilkan nilai $\mathrm{Z}=1.285$, dan $\mathrm{p}=0,074(\mathrm{p}>0,05)$. Hasil uji berdasarkan kaidah menunjukkan sebaran data pola asuh demokratis, interaksi teman sebaya dan kecerdasan emosional adalah normal.

Uji linieritas yang dimaksud untuk mengetahui apakah masing-masing variabel bebas (x) dengan variabel terikat (y) mempunyai hubungan yang linier atau tidak. Sebagai kriterianya apabila p beda $<0,05$ maka dinyatakan mempunyai derajat hubungan yang linier (Nisfiannoor, 2009). Harga-harga hubungan tersebut dilihat pada tabel 4.8 di bawah ini:

Tabel 4.8.

Rangkuman hasil perhitungan Uji linieritas hubungan

\begin{tabular}{cccc}
\hline LINIERITAS & F Beda & p Beda & KET \\
\hline $\mathrm{X}_{1}-\mathrm{Y}$ & 22.460 & 0.000 & Linier \\
\hline $\mathrm{X}_{2}-\mathrm{Y}$ & 9.326 & 0.003 & Linier \\
\hline $\mathrm{X}_{, 1,2}-\mathrm{Y}$ & 15.056 & 0.000 & Linier \\
\hline
\end{tabular}

Hasil uji asumsi linieritas antara variabel pola asuh demokratis dan interaksi teman sebaya dengan kecerdasan emosional mempunyai nilai linearity $F=15.056$ dan $p=0.000$ yang $<0.05$ yang berarti hubungannya dinyatakan linier.

Hasil uji asumsi linieritas antara variabel pola asuh demokratis dengan kecerdasan emosionalmempunyai nilai linearity $\mathrm{F}=22.460$ dan $\mathrm{p}=0.000$ yang $<0.05$ yang berarti hubungannya dinyatakan linier.

Hasil uji linieritas pada variabel interaksi teman sebaya dengan kecerdasan emosional diperoleh nilai linearity $F=9.326$ dan $\mathrm{p}=0.003$ yang $<0.05$.

Hasil analisis menunjukkan bahwa variabel bebas (Pola asuh demokratis dan Interaksi teman sebaya) mempunyai hubungan yang linier terhadap variabel terikat (Kecerdasan emosional).

Berdasarkan hasil analisis dengan metode regresi berganda di dapatkan dua hasil dalam rangka menguji 3 hipotesis yang telah diajukan yakni main effect dan interaction effect. Untuk interaction effect di dapatkan hubungan signifikan antara pola asuh 
Atika Sabaria, Abdul Munir, Cut Metia, Hubungan Pola Asuh Demokratis dan Interaksi Teman

demokratis, Interaksi teman sebaya dengan kecerdasan emosional, dimana koefisien $r=$ 0.518 ; dengan $\mathrm{p}=0.00$ berarti $\mathrm{p}<0,01$. Koefisien determinan ( $\mathrm{r} 2$ ) dari hubungan antara prediktor pola asuh demokratis, interaksi teman sebaya dengan variabel terikat kecerdasan emosional adalah sebesar $\mathrm{r} 2=0.269$. Ini menunjukkan bahwa kecerdasan emosional dibentuk oleh Pola asuh demokratis dan Interaksi teman sebaya dengan konstribusi sebesar $26.9 \%$.

Hasil main effect dari kedua predictor menunjukkan bahwa: Ada hubungan signifikan positif signifikan antara Pola asuh demokratis dengan Kecerdasan emosional, dimana koefisien $r x 1 y=0.461$ dengan $p=0.000$, hal ini berarti semakin tinggi Pola asuh demokratis maka semakin maka semakin tinggi kecerdasan emosional. Koefisien $r$ kuadrat pola asuh demokratis dengan variabel terikat kecerdasan emosional adalah sebesar $\mathrm{r} 2=0,213$. Ini menunjukkan bahwa kecerdasan emosional dibentuk oleh pola asuh demokratis dengan konstribusi sebesar 21.3\%. Ada hubungan signifikan positif antara interaksi teman sebaya dengan kecerdasan emosional, dimana koefisien rx $2 \mathrm{y}=$ 0.318 dengan $\mathrm{p}=0.000$, hal ini berarti semakin tinggi interaksi teman sebaya maka semakin tinggi kecerdasan emosional. Koefisien determinan (r2) dari hubungan antara interaksi teman sebaya dengan variabel terikat kecerdasan emosional adalah sebesar r2 = 0,101 . Ini menunjukkan bahwa kecerdasan emosional dibentuk oleh interaksi teman sebaya dengan konstribusi sebesar $10.1 \%$.

Tabel 4.9 di bawah ini merupakan rangkuman hasil perhitungan Multiple Regresion

Tabel 4.9.

Rangkuman Perhitungan Multiple Reggresion

\begin{tabular}{|c|c|c|c|c|c|}
\hline Output & & Koef $\mathrm{r}$ & Koef $r^{2}$ & $\mathrm{p}$ & $\mathrm{BE} \%$ \\
\hline Interaction effec & $\mathrm{X}_{12}-\mathrm{Y}$ & 0.518 & 0.269 & 0.000 & 26.9 \\
\hline Main effect & $\mathrm{X}_{1}-\mathrm{Y}$ & 0.461 & 0.213 & 0.000 & 21.3 \\
\hline & $\mathrm{X}_{2}-\mathrm{Y}$ & 0.318 & 0.109 & 0.000 & 10.9 \\
\hline \multicolumn{6}{|c|}{ Tabel 4.10. Coefficients } \\
\hline \multirow[t]{2}{*}{ Model } & \multicolumn{3}{|c|}{ Unstandardized Coefficients } & \multirow[t]{2}{*}{ B } & \multirow[t]{2}{*}{ Std. Error } \\
\hline & $\mathrm{B}$ & \multicolumn{2}{|c|}{ Std. Error } & & \\
\hline (Constant) & 8.507 & \multicolumn{2}{|c|}{10.280} & 0.828 & 0.410 \\
\hline Pola Asuh & 0.522 & \multicolumn{2}{|c|}{0.121} & 4.334 & 0.000 \\
\hline \multicolumn{6}{|l|}{ Demokratis } \\
\hline Interaksi & 0.432 & \multirow{2}{*}{\multicolumn{2}{|c|}{0.173}} & 2.497 & 0.015 \\
\hline Teman Sebaya & & & & & \\
\hline
\end{tabular}

Dependent Variable: Kecerdasan Emosi

Jika tingkat kesalahan ditentukan sebesar 5\%, maka kita dapat melihat nilai t pada masing-masing variabel adalah $\mathrm{X} 1=4.334$ dengan harga $\mathrm{p}=0,000, \mathrm{X} 2=2.497$ dengan harga $p=0,015$. Dengan demikian, harga $p$ variabel $X 1, p<0,05$ berarti variabel bebas X1 Pola asuh demokratis dapat menjelaskan variabel bergantung kecerdasan emosi dan $\mathrm{X} 2$ harga $\mathrm{p}<0,05$, hal ini menunjukkan bahwa variabel bebas X2interaksi teman sebaya bisa menjelaskan variabel bergantung Ykecerdasan emosional. Maka dapat disimpulkan bahwa persamaan linier berganda $\mathrm{Y}=\mathrm{a}+\mathrm{bX} 1+\mathrm{cX} 2$ berlaku, dalam hal ini variabel pola asuh demokratis dapat berdiri sendiri atau bersamaan dalam mempengaruhi variable 
terikat kecerdasan emosional demikian halnya dengan variable interaksi teman sebaya, variable interaksi teman dapat berdiri sendiri mempengaruhi kecerdasan emosional, maupun secara bersamaan dengan variable polaasuh demokratis.

\section{Mean Hipotetik}

Variabel Pola asuh demokratis dalam penelitian ini mempunyai 38 item. Setiap item mempunyai 2 alternatif jawaban maka mean hipotetiknya (MH) adalah $\{(38 \times 1)+(38 \times 2)\}$ / 2 = 57.00. Variabel Interaksi teman sebaya dalam penelitian ini mempunyai 24 item. Setiap item mempunyai 2 alternatif jawaban maka mean hipotetiknya (MH) adalah $\{(24 \times$ 1) $+(24 \times 2)\} / 2=36.00$. Variabel Kecerdasan emosional dalam penelitian ini mempunyai 35 item. Setiap item mempunyai 2 alternatif jawaban maka mean hipotetiknya (MH) adalah $\{(35 \times 1)+(35 \times 2\} / 2=52.500$.

\section{Mean Empirik}

Hasil perhitungan mean empirik variabel Pola asuh demokratis dalam penelitian ini adalah 70.106, variabel Interaksi teman sebaya 44.047, dan variabel Kecerdasan emosional adalah 64.176.

\section{Standar Deviasi}

Nilai standar deviasi (SD) dari variabel Pola asuh demokratis dalam penelitian ini adalah 3.512, variabel Interaksi teman sebaya sebesar 2.444 dan variabel Kecerdasan emosional sebesar 4.403 .

\section{Kriteria}

Dalam upaya mengetahui bagaimana kondisi Pola asuh demokratis, Interaksi teman sebaya dan Kecerdasan emosional, maka perlu dibandingkan antara mean hipotetik dengan mean empirik, dengan memperhatikan nilai standar deviasi dari variabel yang sedang diukur. Jika $\mathrm{MH}<\mathrm{ME}$, dimana selisihnya melebihi SD, maka dinyatakan bahwa Pola asuh demokratis, interaksi teman sebaya dan kecerdasan emosional dikatakan kuat demikian sebaliknya, Jika MH > ME, dimana selisihnya melebihi SD, maka dinyatakan bahwa Pola asuh demokratis, interaksi teman sebaya dan kecerdasan emosional dikatakan lemah. Jika selisih MH dengan ME tidak melebihi SD, maka dinyatakan bahwa Pola asuh demokratis, interaksi teman sebaya dan kecerdasan emosional dikatakan sedang.

Tabel 4.11.

Hasil Perhitungan Nilai Rata-rata Hipotetik dan Nilai Rata-rata Empirik

\begin{tabular}{ccccc}
\hline \multirow{2}{*}{ Variabel } & SD & \multicolumn{2}{c}{ Nilai Rata-Rata } & Ket \\
\cline { 2 - 4 } & 4.402 & 52.500 & 64.176 & Tinggi \\
$\begin{array}{c}\text { Kecerdasan } \\
\text { emosional }\end{array}$ & 3.512 & 57.000 & & \\
\hline $\begin{array}{c}\text { Pola asuh } \\
\text { demokratis }\end{array}$ & 36.000 & 70.106 & Tinggi \\
\hline $\begin{array}{c}\text { Interaksi } \\
\text { teman sebaya }\end{array}$ & 2.444 & 36.000 & 44.047 & Tinggi \\
\hline
\end{tabular}


Pembahasan hipotesis pertama: Hasil penelitian ini menunjukan bahwa terdapat hubungan pola asuh demokratis dan interaksi teman sebaya dengan kecerdasan emosional, yang ditunjukkan oleh koefisien koefisien $r=0.518$; dengan $p=0.00$ berarti $p$ $<0,01$. Artinya semakin tinggi pola asuh demokratis dan interaksi sebaya maka semakin tinggi kecerdasan emosional, sebaliknya semakin rendah pola asuh demokratis dan interaksi teman sebaya maka semakin rendah kecerdasan emosional.

Kecerdasan emosional penting dimiliki anak agar mampu mengontrol perilakunya dalam berinteraksi dengan orang lain maupun bertindak di dalam kehidupan. Kecerdasan emosional dapat menempatkan emosi seseorang pada porsi yang tepat, memilah kepuasan dan mengatur suasana hati adalah inti dari hubungan sosial yang baik. Kecerdasan emosional yaitu kesanggupan untuk mengendalikan dorongan emosi, untuk membaca perasaan terdalam orang lain, dan untuk memelihara hubungan dengan sebaikbaiknya. Kecerdasan emosional sangat dipengaruhi oleh faktor lingkungan keluarga (pola asuh orang tua), lingkungan luar keluarga (sekolah dan interaksi teman sebaya), tidak bersifat menetap dan dapat berubah-ubah setiap saat. Untuk itu peranan lingkungan terutama orang tua dan lingkungan luar keluarga sangat mempengaruhi dalam pembentukan emosional khususnya pada masa anak-anak, Mubayidh (2007).

Emosional dipengaruhi oleh dasar biologisnya dan juga pengalaman masa lalu (Santrock, 2007). Pengalaman masa lalu yang tercermin dalam pembentukan emosional dipengaruhi oleh peran keluarga. Di dalam keluarga, orang tua mempunyai peran lebih banyak dalam mengawal tumbuh kembang anak. Orang tua mempunyai peran penting dalam mendampingi dan membentuk perkembangan emosional anak.

Seperti yang diungkapkan oleh Yunus, Sri Lestari \& Kasim (2015) dalam penelitian yang dilaksanakannya yaitu terdapat hubungan antara pola asuh demokratis dengan kecerdasan emosional, peran dan keterlibatan orang tua dalam pelaksanaan pola asuh sangat diperlukan untuk mengembangkan kecerdasan emosional anak. Hal senada diungkapkan oleh Hidayatullah (2015) dalam penelitan yang dilaksanakannya adanya hubungan antara pola asuh orangtua dengan kecerdasan emosional pada anak dengon bobot sumbangan pola asuh demokratis sebesar 52,9\% dan kecerdasan emosional 44,1\% pola asuh ini sangat kondusif untuk mendukung pembentukan kepribadian yang prososial, percaya diri dan mandiri namun sangat perduli dengan lingkungannya.

Orangtua akan mendidik anaknya dengan pola asuh yang berbeda-beda. Pola asuh inilah yang akan menentukan kecerdasan emosional anak. Disamping pola asuh yang telah diterapkan oleh orangtua, interaksi dengan teman sebaya juga akan berpengaruh terhadap kecerdasan emosional. Anak tentu saja memerlukan teman dan hubungan teman baik di lingkungan sekitar maupun lingkungan sekolah akan mempengaruhi kecerdasan emosional.

Berdasarkan pada hasil penelitian ini, maka dapat dinyatakan bahwa pola asuh demokratis dan interaksi teman sebaya mempunyai peranan penting dalam membentuk perkembangan kecerdasan emosional anak, kecerdasan emosional dibentuk oleh Pola asuh demokratis dan Interaksi teman sebaya dengan konstribusi sebesar 26.9\% sedangkan sisanya $73.1 \%$ berasal dari faktor lain. Anak yang memiliki kecerdasan emosional yang baik lebih mampu untuk mengatur emosinya dan menempatkan diri pada 
berbagai situasi yang tak terduga. Hal ini tentu sangat menunjang dalam lingkup interaksi dengan teman sebayanya, peran orangtua akan tercermin dalam pola asuh yang mereka gunakan dalam mendidik anak.

Pembahasan hipotesis kedua : Hasil penelitian ini menemukan bahwa terdapat hubungan yang sangat signifikan antara pola asuh demokratis dengan kecerdasan emosional yang di tunjukan oleh koefisien koefisien $r x 1 y=0.461$ dengan $p=0.000$, hal ini berarti semakin tinggi pola asuh demokratis maka semakin maka semakin tinggi kecerdasan emosional. Koefisien $r$ kuadrat pola asuh demokratis dengan variabel terikat kecerdasan emosional adalah sebesar $\mathrm{r} 2=0,213$. Ini menunjukkan bahwa kecerdasan emosional dibentuk oleh pola asuh demokratis dengan konstribusi sebesar $21.3 \%$.

Salah satu pola asuh yang dapat mengembangkan kecerdasan emosional anak adalah pola asuh demokratis. Soeloeman (dalam Wulansari 2014) mengungkapkan bahwa di dalam keluarga yang menerapkan pola asuh demokratis, seorang anak akan memperoleh latihan-latihan dasar dalam mengembangkan sikap sosialnya yang baik dan kebiasaan berperilaku. Sikap sosial dan kebiasaan berperilaku merupakan kecerdasan emosional. Anak yang memiliki kecerdasan emosional yang baik akan lebih mudah menyesuaikan diri dengan lingkungan, terutama dengan teman sebayanya dan dapat berlaku ramah dengan orang lain.

Pola asuh orang tua demokratis bercirikan adanya kebebasan dan ketertiban, orangtua memberikan arahan atau masukan-masukan yang sifatnya tidak mengikat kepada anak. Dalam hal ini orangtua bersifat objektif, perhatian dan kontrol terhadap perilaku anak-anaknya, sehingga orangtua dapat menyesuaikan dengan kemampuan anak, Bolson (dalam Andrie, Winarti dan Utami, 2001). Dengan kata lain, pola asuh demokratis ini memberikan kebebasan kepada anak untuk mengemukakan pendapat, melakukan apa yang diinginkannya dengan tidak melewati batas-batas atau aturan-aturan yang telah ditetapkan orang tua.

Selanjutnya Surbakti (2009) menyatakan pola asuh orangtua memiliki peran yang sangat penting terhadap perkembangan kecerdasan emosional pada anak. Kegagalan pola asuh orangtua sering kali menjadi faktor penyebab terjadinya gangguan pada perkembangan kecerdasan emosional anak. Hal senada diungkapkan oleh Fatmawati, Amanto Yudi Ismanto \& Abram Babakal (2015) dalam penelitian yang di laksanakannya adanya kaitan erat antara kecerdasan emosional dengan pola asuh orangtua. Ini akan sangat mempengaruhi kepribadian, bahkan mungkin kegagalan atau kesuksesannya, untuk itu peranan lingkungan terutama orang tua sangat mempengaruhi dalam pembentukan emosional anak.

Pembahasan hipotesis ketiga : Hasil penelitian ini menentukan bahwa terdapat hubungan signifikan positif antara Interaksi teman sebaya dengan kecerdasan emosional, dimana koefisien $r x 2 y=0.318$ dengan $p=0.000$, hal ini berarti semakin tinggi Interaksi teman sebaya maka semakin tinggi kecerdasan emosional. Koefisien determinan (r2) dari hubungan antara interaksi teman sebaya dengan variabel terikat kecerdasan emosional adalah sebesar $\mathrm{r} 2=0,101$. Ini menunjukkan bahwa kecerdasan emosional dibentuk oleh Interaksi teman sebaya dengan konstribusi sebesar $10.1 \%$. 
Salah satu fungsi terpenting teman sebaya adalah memberikan sumber informasi dan perbandingan tentang dunia di luar keluarga (Santrock, 2007). Interaksi dengan teman sebaya akan memberikan pengalaman yang berbeda dari keluarga. Perbedaan pengalaman dalam keluarga dan di luar keluarga membuat anak beradaptasi dengan bantuan teman sebaya. Hartub (dalam Desmita, 2007) menyatakan bahwa bagi anak usia sekolah, teman sebaya (peer) mempunyai fungsi yang hampir sama dengan orangtua. Hal ini bisa disebabkan karena kadang teman sebaya dapat memberikan pengaruh lebih kepada perilaku anak, baik perilaku positif maupun perilaku negatif.

Anak menghabiskan sebagian besar waktu berinteraksi dengan teman sebayanya di sekolah, terutama dengan teman-teman sekelas. Perilaku menyimpang yang dilakukan anak karena pengaruh teman sebaya sangat banyak ditemukan. Hal ini senada dengan pendapat Yusuf (2006) yang menyatakan bahwa penelitian yang dilakukan Glueck dan Glueck yang menemukan bahwa terdapat hubungan positif antara interaksi teman sebaya dengan kecerdasan emosional. Hal senada seperti yang diungkapkan oleh Ammar (2014) pada penelitiannya menyimpulkan kaitan erat antara interaksi teman sebaya dengan kecerdasan emosional, dalam berinteraksi, kemampuan mengenali emosi orang lain dan membina hubungan semakin terasa. Interaksi yang tinggi dan bersifat positif mampu mengembangkan kemampuan-kemampuan kecerdasan emosional.

Berdasarkan mean empirik dan mean hipotetik variabel pola asuh demokratis dalam penelitian ini adalah $(70.106>57.00)$, variabel Interaksi teman sebaya (44.047 > 37.00), dan variabel kecerdasan emosi adalah (64.176 > 52.500) diketahui bahwa subjek penelitian memiliki pola asuh demokratis, interaksi teman sebaya dan kecerdasan emosional yang tinggi.

\section{SIMPULAN}

Berdasarkan hasil analisis data yang telah diperoleh dalam penelitian ini, maka dapat ditarik kesimpulan sebagai berikut: Ada hubungan yang signifikan antara pola asuh demokratis dan interaksi teman sebaya dengan kecerdasan emosional, yang ditunjukkan oleh koefisien $r=0.518$; dengan $p=0.00$ berarti $p<0,01$. Hal ini berarti semakin tinggi pola asuh demokratis dan interaksi teman sebaya maka semakin tinggi kecerdasan emosional. Dengan sumbangan sebesar 26.9\%; Ada hubungan yang signifikan antara pola asuh demokratis dengan kecerdasan emosional, yang ditunjukan oleh koefisien rx1y = 0.461 dengan $\mathrm{p}=0.000$. Hal ini berarti semakin tinggi pola asuh demokratis maka semakin maka semakin tinggi kecerdasan emosional. Dengan sumbangan sebesar 21.3\%; Ada hubungan yang signifikan antara interaksi teman sebaya dengan kecerdasan emosional, yang ditunjukan oleh koefisien $r x 2 y=0.318$ dengan $p=0.000$. Hal ini berarti semakin tinggi Interaksi teman sebaya maka semakin tinggi kecerdasan emosional. Dengan sumbangan sebesar 10.9\%; Berdasarkan mean empirik dan mean hipotetik variabel pola asuh demokratis dalam penelitian ini adalah $(70.106>57.00)$, variabel Interaksi teman sebaya (44.047 > 37.00), dan variabel kecerdasan emosi adalah (64.176 > 52.500) diketahui bahwa subjek penelitian memiliki pola asuh demokratis, interaksi teman sebaya dan kecerdasan emosional yang tinggi.] 


\section{DAFTAR PUSTAKA}

Asrori, A., Hidayat, T., \& Nugroho, A.N. (2009). Hubungan Kecerdasan Emosi dan Interaksi Teman Sebaya dengan Penyesuaian Sosial Pada Siswa. Laporan Penelitian. Surakarta: Fakultas Kedokteran Universitas Sebelas Maret.

Ammar, A, M. (2014). Hubungan Antara Interaksi Teman Sebaya Dengan Kecerdasan Emosional Siswa Kelas V SDN 1 Bedegas. Skripsi. Yogyakarta: Fakultas Ilmu Pendidikan.

Andri, W, dan Utami. (2001). Pola Asuh Orang Tua dan Nilai-Nilai Kehidupan yang Dimiliki Oleh Remaja. Fenomena: Laporan Penelitian. Yogyakarta: Fakultas Psikologi.

Desmita. (2007). Psikologi Perkembangan. Bandung: Remaja Rosdakarya.

Hartaty, D.W. \&, Azis, A., (2014) Hubungan Antara Pola Asuh Otoritarian Dan Konformitas Teman Sebaya Dengan Kenakalan Remaja, Analitika: 6 (1): 1-8

Fadilah, R., Parinduri, S.A., Syaimi, K.U., Suharyanto, A. (2020). Islamic Guidance and Counseling to Overcome The Study Difficulty of Junior High School Students in SMP IT Nurul Azizi Medan (Case Study of Students Experiencing Anxiety). International Journal of Psychosocial Rehabilitation

Fatmawati, A.Y.I., \& Babakal, A. (2015). Hubungan Pola Asuh Orang Tua Dengan Kecerdasan Emosional Pada Anak Usia Remaja Dikelurahan Soasio Kota Tidore Kepulauan. ejournal keperawatan (e-Kp) Volume 3 Nomor 2 Mei 2015

Goleman, D. (2016). Emotional Intelligence, Mengapa EI Lebih Penting Daripada IQ. (Terjemahan : T Hermaya). Jakarta : PT. Gramedia Pustakan Utama.

Hadi, S. (2004). Metodelogi Reaserch. Yogyakarta: Andi.

Hamdani, R., Lahmuddin L., Aziz, A., (2015), Hubungan antara Dukungan Sosial dan Kecerdasan Emosional dengan Self-Regulated Learning Siswa. Analitika: 7 (2): 105-117

Harahap, E.R., Ferry N., Gustiarti L., (2014), Peranan Kohesivitas Kelompok Dan Kecerdasan Emosional Terhadap Organizational Citizenship Behavior, Analitika: 6 (1): 1-10

Hasmayani, B., Hotman S., (2012), Perbedaan Minat Sekolah dan Motivasi belajar Ditinjau dari Pola Asuh Orangtua, Analitika: 4 (1): 24-30

Hidayatullah, F.A. (2014) Hubungan Pola Asuh Orangtua Dengan Kecerdasan Emosional Pada Anak Prasekolah (3-5 Tahun) Di KB-TK Anak Cerdas PP PAUDNI Regional II Semarang. Laporan Penelitian. Semarang : Program Studi D-IV Kebidanan.

Mubayidh, M. (2007). Kecerdasan dan Kesehatan Emosional Anak. Jakarta : Pustaka Al Kautsar.

Nisfiannoor, M, (2009). Pendekatan Statistika Modern untuk Ilmu Sosial. Jakarta: Salemba Humanika.

Novita, E., (2012), Perbedaan Agresivitas Ditinjau dari Pola Asuh Orang Tua, Analitika: 4 (2): 53-56

Pandia, W.H, Abdul M., Azhar A., (2015) Hubungan Harga Diri Siswa dan Pola Asuh Demokratis Orangtua dengan Motivasi Belajar Siswa, Analitika: 7 (2): 80-87

Salamiah S, N.S., Dini, H.S., (2011), Hubungan Intelegensi Dan Pola Asuh Orangtua Demokratis Dengan Harga Diri Siswa, Analitika: 3 (2): 99-114

Santrock, J. W. (2007). Perkembangan Anak Jilid 2. Penerjemah: Mila Rachmawati. Jakarta: Erlangga.

Sleman Kabupaten Sleman Tahun 2013. Skripsi. Yogyakarta : Fakultas Ilmu Pendidikan.

Surbakti, M.A. (2009). Kenalilah Anak Remaja Anda. Jakarta :PT Elex Media Komputindo

Syarifah, \& Nefi D., (2010), Pengaruh Locus Of Control dan Kecerdasan Emosional terhadap Kemampuan Memecahkan Masalah pada Remaja Desa Percut Kecamatan Percut Sei Tuan, Analitika: 2 (2): 88-98

Wulansari, M. (2014). Hubungan Pola Asuh Orang Tua dan Lingkungan Sekolah Dengan Kecerdasan Emosional Pada Anak Siswa SD Kelas V Keceme I,

Yunus, S.L., \& Kasim. (2015). Hubungan Pola Asuh Demokratis Dengan Kecerdasan Emosional Pada Remaja di SMA Negeri 4 Kota

Zuraida, Kaiman T, Sri S, (2015), Hubungan Kecerdasan Emosional dan Dukungan Sosial Keluarga dengan Burnout, Analitika: 7 (2): 141-149 